\title{
The Image of China Shaped by American Missionaries and Its Impact in the Early Twentieth Century
}

\author{
WANG Jing*
}

Among Westerners in modern China, missionaries were most numerous, and they knew the people best. They spread widely throughout the country, got in closer touch with the people, spoke their language, and through preaching the Gospel, education, medical endeavors, and charity missions, were involved in the modern transition of China. More eager than merchants or diplomats, missionaries dedicated themselves to introducing Western civilization, and especially Christianity, to China, and meanwhile also introduced China to the West. Staying more continuously than journalists and tourists, missionaries provided information to Chinese in their homeland, and to the Western world through letters to family, reports to home missions, speeches, and books.

American missionaries were the main force in the Protestant missionary movement in the twentieth century, while missionaries from England played a more important role in most of the nineteenth century. Attracting more missionaries, China, in the 1890s, replaced India as the chief mission field. Later American involvement in Asia grew in the wake of the SpanishAmerican War, Open Door Policy, and Boxer Uprising in China. China captured more attention from American churchgoers, clergymen, and their congregations.

When missionaries came to China in nineteenth century, they saw an old, conservative, stagnate, and heathen empire. As China gradually opened to the world, missionaries came to know the country and its people better and felt the changes in China, but in a good part of the nineteenth century, missionaries mostly entertained negative impressions of China rather than positive ones, except for a few missionary scholars (such as S. W. Williams, W. A. P. Martin, Gilbert Reid, and Arthur. H. Smith), who discovered a world that inspired admiration. To create interest in China mission work, missionaries painted a dark picture of Chinese heathenism, eliciting a great degree of

* 王静 Lecturer, School of Humanities, China University of Political Science and Law. 
sympathy for the people of China. Paul A. Varg wrote, "Few missionaries were psychologically prepared or trained to make an analysis of social institutions and consequently, in reporting their experiences, dwelt on the strange and the unusual. Having gone to China dedicated to building a new society, they found in the old nothing but arguments to justify their cause." 1

\section{Reforms in the Late-Qing Period}

Missions sustained tremendous losses during the Boxer Uprising of 1900, but churches all over the country withstood the great tribulation, which greatly gratified missionaries. The faith of Chinese Christians was particularly appreciated by missionaries: "The behaviour, during the late Convulsion, of the native Christians of China, as a whole, has added a new and thrilling chapter to the Evidences of Christianity."2 Generally, the church quickly recovered from the uprising that shook China. Heavy loss of life and property made Christians in Western countries pay more attention to this field and also attracted more missions and missionaries to China. Stable development of churches made missionaries take an optimistic view.

For missionaries, China entered a new era after the Boxer episode, as recounted in The Chinese Recorder (January 1901): "History has been made in China as never before, and the world, we may say, has been a participator. China in spite of herself has entered upon a new era, and she can never go back. The spell of Christianity, of modern civilization, of progress and improvement, is upon her." 3 After the upheaval, missionaries perceived that the Chinese were more open-minded, as in Shanxi, where the Boxer Uprising wrecked havoc. According to C. A. Stanley, "[There is] a state of things among all classes different from that of a few years ago. There is manifest on all sides a greater desire to protect foreign life and property than formerly.... Civil and military officials are more courteous and respectful than formerly .... Scholars and the gentry - the men of influence in every community - are more social and willing to come into friendly relations with us as never before. This means much as regards the ordinary rank and file. They are more accessible to the gospel. "4 The railway, the telegraph, the newspaper, and the post office, C. A. Stanley continued, helped to spread information and foster the spirit of communication and friendly interchange of

1 Paul A. Varg, Missionaries, Chinese, and the Diplomats: The American Protestant Missionary Movement in China (Princeton: Princeton University Press, 1977), p. 106.

2 Arthur H. Smith, China in Convulsion (New York: Fleming H. Revell Co., 1901), Preface, p. xi.

3 "Happy New Year," Chinese Recorder 32 (January 1901): 52.

4 C. A. Stanley, "The New Conditions in China," Chinese Recorder 35 (June 1904): 291. 
thought, with the result that the Chinese mindset finally evolved away from the notion that only the sages were worth emulating. 5

A significant consequence of the Boxer Uprising was that, along with the development of missions and accommodation of Chinese, it helped also to change missionary minds regarding China. The American scholar John B. Gardner clearly stated,

The Boxer uprising of 1900 made the missionaries acutely conscious of their role in China. The missionaries were subjected to heavy criticism from parts of the American Press and other sources as intruders in China upon whom should fall a major share of the blame for the uprisings. They found themselves defending a role which it would never occur to most to defend. Even as the missionary denied any blame for the uprisings and asserted the benefits he had brought to the Chinese, one may surmise that he was more careful to temper the nature of his comments about China. 6

Gardner's analysis is quite sharp. Missionaries were dismayed that they and their Chinese converts were targets of the Boxers, so they stopped emphasizing 400 million heathen and instead emphasized accomplishments achieved with invested funds and through missionary efforts. ${ }^{7}$

After a series of reforms were instituted, missionaries' attitudes to China and its condition tended toward the positive. Considered as signs of progress were the imperial decree that ordered the inauguration of a new system of education, and the imperial edict that abolished the time-honored one and directed that in the future candidates for degrees and offices should submit short essays on such modern topics as Western science, governments, laws, and kindred subjects. Missionaries were eager for reform in China and were moved by efforts of the government and people. In his book Rex Christus, A. H. Smith pointed out, "The vast bulk of the Chinese Empire helps to disguise the fact that for some years it has been making rapid progress, even at times when to the eye nothing was apparent but retrogression." 8

Arthur J. Brown, Secretary of the Board of Foreign Missions of the Presbyterian Church in the United States, wrote in 1904 that besides Japan,

5 C. A. Stanley, "The New Conditions in China," Chinese Recorder 35 (June 1904): 293.

6 John Berdan Gardner, "The Image of the Chinese in the United States, 1885-1915," doctoral dissertation, University of Pennsylvania, 1961, p. 145.

7 John Berdan Gardner, The Image of the Chinese in the United States, 1885-1915, p. 146.

8 Arthur H. Smith, Rex Christus: An Outline Study of China (New York: Macmillan, 1903), Preface, p. vii. 
with its meteoric progress, "there is another race in Asia, which, though now moving sluggishly, has possibilities of development that may in time make it a dominant factor in the future of the world."9 Brown's book, New Forces in Old China, described how the three great transforming forces of the modern world - Western trade, politics, and religion — operated on the tradition-bound and exclusive ways of old China. Brown observed, "There is something fascinating and at the same time something appalling in the spectacle of a nation numbering nearly one-third of the human race slowly and majestically rousing itself from the torpor of ages under the influence of new and powerful revolutionary forces. No other movement of our age is so colossal, no other is more pregnant with meaning."10 Brown emphasized in his work how noble it was "to grasp the great thought that the Chinese is not only a man, but our brother man, made like ourselves in the image of God." $11 \mathrm{He}$ also listed many Chinese virtues deserving respect, as industriousness, intelligence, endurance, and so on. Brown's work included his experience of visiting China in 1901-1902, thus providing first-hand information of China. We should also note that Brown showed great sympathy for China. Arthur $\mathrm{H}$. Smith, in his review of this book, commented that this book has "a force and conviction not always met with in works treating of China and the Chinese" and "should find place in every self-respecting library undertaking to keep its readers abreast of the times."12 A review of Brown's book also appeared in the New York Times. This latter review was less optimistic than Brown's work. ${ }^{13}$ Because it focused on other subjects, such as railways, education, opportunities for missionaries, the review almost failed to mention Brown's respect for the Chinese and the far-reaching meaning of China's awakening. In the end, it said that Mr. Brown's volume deserved general reading.

In 1905 Japan gained a decisive victory over Russia, as missionaries expected. For missionaries, a Japanese victory was a positive force for China. As A. P. Parker stated in one article, "A Japanese victory must necessarily have a further result, in producing a liberalizing effect on the minds of the Chinese." Moreover, "if Japan comes out victorious from this struggle, ... China will realize more fully than ever that what Japan has done

9 Arthur J. Brown, New Forces in Old China: An Unwelcome but Inevitable Awakening (New York: Fleming H. Revell Co., 1904), p. 17.

10 Arthur J. Brown, New Forces in Old China: An Unwelcome but Inevitable Awakening, Preface, p. 5.

11 Arthur J. Brown, New Forces in Old China: An Unwelcome but Inevitable Awakening, p. 33 .

12 Arthur H. Smith, Review, Chinese Recorder 36 (February 1905): 90.

13 "Old China: Arthur Judson Brown's Book about the New Forces Now Developing There," New York Times, January 7, 1905. 
by tolerating Christianity and adopting Western ideas, China can do by following the same methods." 14 The Russo-Japanese War did indeed have a profound effect on China. In September 2, 1905, the time-honored system of the civil-service examination was abolished by the imperial government-an event that gained much praise from missionaries. William N. Brewster even wrote, "September 2d, in the year 1905, will go down in history as the birthday of the New China." 15 In the same year, the boycott of American products as protest against the U.S. Chinese Exclusion Act was considered an indication of new life in China by many missionaries. More missionaries suggested carefully studying the new condition in China. The terms "new condition," "new era," and "new China" were frequently used in missionaries' articles, journals, and books to describe China. The Missionary Herald sketched the changes in China from 1900 to 1905 thus: "The Boxer cataclysm is known to all the world. That was the crack of doom for paganism, and the beginning of mighty changes in this ancient empire. Of late the roar of cannon in Manchuria has been heard in Peking, and slumbers ages old are disturbed.... A new China is knocking at the door of the American churches." 16

Two remarkable reforms in 1906 attracted more attention from missionaries. The first was that the imperial government promised to grant constitutional government. Meetings were held in important centers to celebrate this proclamation. Chinese Christians also held meetings to discuss topics related to constitutional government. In The Chinese Recorder, E. I. Osgood expressed the new condition of China: "A universal desire for change has taken hold of China.... New schools on modern lines have sprung up over the entire empire.... The government is being made to understand that it no longer exists for the selfish interests of its rulers.... Demands for a national constitution and reorganization of the army are being answered.... Footbinding, the queue, forms of clothing, kinds and quality of foods, female education, style of architecture, extraterritoriality, all are becoming popular questions for discussion." 17 The other reform attracting attention was the imperial decree of September 20, 1906, prohibiting opium. Missionaries sought to prohibit opium for a long time, and they appreciated the courage of

14 A. P. Parker, "Probable Effects of the Russo-Japanese War on Protestant Mission Work in China," Chinese Recorder 36 (May 1905): 241-243.

15 William N. Brewster, The Evolution of New China (Cincinnati: Jennings and Graham, 1907), p.65.

16 Quoted in Sidney A. Forsythe, An American Missionary Community in China, 1895-1905 (Cambridge: Harvard University Press, 1971), pp. 58-59.

17 E. J. Osgood, "How Can We Best Meet the New Conditions Which Are Coming into Ascendancy in China," Chinese Recorder 37 (September 1906): 486. 
the government in enacting this "most startling reform." S. Isett Woodbridge frankly noted, "It would be a victory greater than that achieved by the armies and fleet of Japan if China would do with opium what America cannot do with liquor-abolish it." 18

Around 1907 missionaries marveled at the progress of China since the Boxer Uprising. J. W. Bashford commented, "The present movement is an attempt to modify the existing civilization and bring China out as a modern nation. The most striking fact in modern history is the awakening of China in the last five years." 19 Besides China's authentic progress, missionaries also highly valued Chinese reforms at this time. The year 1907 meant much to missionaries. For one, it was the centenary year of Protestant Christianity in China. Christian developments in China far surpassed missionaries' expectations and enhanced their optimism. As missionaries looked back on changes in China from 1807 to 1907, the progress of China was self-evident. Meanwhile, they not only focused on political reform, also paid attention to business, religion, education, and communication. Several books were published on the Protestant centenary, including W. S. Ament's The Giant Awakened (1906), J. W. Bashford's China and Methodism (1906), Arthur H. Smith's The Uplift of China (1907), W. A. P. Martin's The Awakening of China (1907), and William N. Brewster's The Evolution of New China (1907). Through these books we know missionaries' views of China. Significantly, Arthur J. Brown, in the revised edition of New Forces in Old China: An Unwelcome but Inevitable Awakening, deleted "unwelcome" from the title. ${ }^{20}$ Just one word was deleted, but the change precisely captured the change in Chinese attitude toward the foreign world. The most remarkable book was The Uplift of China, which "sold over 75,000 copies in 1907 and went through numerous editions." 21 While it is difficult to estimate the influence of these books upon readers' understanding of China, it undoubtedly was substantial. According to Keith M. Kindred's research on four leading missionary periodicals, after 1905 books, like The Awakening of China, generally took on a more scholarly tone and emphasized the growing importance of China to American interests. Not coincidentally, the missionary periodicals from 1905 to 1915 that Kindred examined had sections devoted to reviews of

18 S. Isett Woodbridge, "Retrospect and Prospect," Chinese Recorder 38 (January 1907): 4.

19 J. W. Bashford, China and Methodism (Cincinnati: Jennings and Graham, 1906), p. 90.

20 Arthur J. Brown, New Forces in Old China: An Inevitable Awakening (New York: Young People's Missionary Movement, 1907).

21 James Reed, The Missionary Mind and American East Asia Policy, 1911-1915 (Cambridge: Harvard University Press, 1983), p. 24. 
missionary literature, and they promoted books of this type. ${ }^{22}$

During these times, democratic ideas were disseminated throughout the entire world. Their impact on China interested some missionaries, whose opinion was that China could not remain autocratic indefinitely. W. M. Ashmore and William N. Brewster were the most typical. W. M. Ashmore analyzed the distribution of democratic ideas in Asia. He found that India began to change under English administration, and that Japan had a parliament with upper and lower houses. As for China, "Her wars have taught her much; her statesmen sent to distant lands are, some of them, sounding a new rallying cry.... The native press has achieved a prominence and a success as an educator of the public mind.... English-speaking Chinese, not many in number, but influential beyond all proportion to their number, ... are imbibing dangerous teachings from the English newspapers they read. The books and the publications issued by the Diffusion Society and distributed at the examinations are awakening thousands of capable intellects.... The outcome of which will be fatal to despotism and favorable to enfranchisement." 23 William N. Brewster stated, "The days of government by imperial decree in China are numbered." 24 The reasons he mentioned were similar to Ashmore's: the lessons of the Russo-Japanese war and the experiences of the Constitutional Commission.

Democracy would won the final victory in China, but who, the imperial government or some other force, could lead China toward democracy, the missionaries were not so sure. Missionaries were inclined toward a stable political situation and environment, along with the late-Qing reforms and the development of Christianity. Changes leading to a modern society had taken place in India, Turkey, and Persia. As the missionaries observed the situation, "Both in Turkey and in Persia it is not the monarchical idea which is overthrown, but rather the despotic. In spite of the revolutions in these centers republicanism seems to make no advance." 25 China missionaries did not want the country to follow in Persia's footsteps, so they argued that China's "integrity is far preferable to the chaos that would follow an armed revolution." 26

After 1908 there were fewer missionary books on China than during the

22 Keith Matthew Kindred, "Images of the Chinese as Presented in American Protestant Missionary Periodicals, 1905-1915," master thesis, Eastern Michigan University, 1998, p. 32.

23 W. M. Ashmore, "Permeation of the Asiatic Mind with Democratic Ideas," Chinese Recorder 32 (November 1901): 535.

24 William N. Brewster, The Evolution of New China, p. 51.

25 Editorial, "The Overthrow of the Shah," Chinese Recorder 40 (August 1909): 213.

26 E. I. Doty, "The Dragon's Awakening," Chinese Recorder 39 (April 1908): 213. 
Protestant centenary. As before, missionaries continued to use "awakening" and "new era" with reference to China, thus maintaining their optimistic attitude toward China. Although China had not been transformed into a democracy peacefully, as missionaries had expected, the 1911 Revolution and the founding of a republic stirred up their hopes for China.

\section{The 1911 Chinese Revolution}

On the 1911 Revolution, missionaries' attitudes were obviously different from those of other foreigners in China; they gave the movement universal approval and encouragement, in contrast to cautious diplomats and merchants. Fernand Farjenel, a French professor who traveled all over China during the revolution, observed, "Among the foreigners it was the missionaries of various creeds who most ardently desired the success of the republican cause." 27 He reasonably concluded that a great many of the revolutionaries were Christians, and that the birth of the republic would bring about religious liberty. I will discuss the religious factors later. He also noticed that missionaries possessed a more intimate knowledge of the Chinese. This perception was quite sharp. Former Harvard President Charles W. Eliot stated this point more clearly:

Yet I am sorry to say that the lay representatives of the Western peoples, the Occidentals living in China, diplomatic, consular, commercial, or industrial, have seldom manifested during the past year genuine sympathy with this immense effort on the part of a few hundred thousand men out of the huge population of China. It is very possibleindeed, common - for a foreign merchant to remain a whole generation in China and never make the acquaintance of a single Chinese gentleman. An English merchant, who had been conducting thirty-five years a successful, widespread business in China, told me that he did not know a single word of Chinese, or a single Chinese man except his comprador.... Think what that implies concerning the probable ignorance of the Occidental resident in China concerning the Chinese people, their qualities, their hopes, and their aspirations. The Western people in China who really know something about the Chinese are missionaries, teachers, and other foreigners who go to China, and stay there, with some philanthropic purpose, or hope of doing good. ${ }^{28}$

27 Fernand Farjenel, Through the Chinese Revolution, translated from the French by Margaret Vivian (London: Duckworth and Co., 1915), p. 99.

28 Quoted in F. L. Hawks Pott, The Emergency in China (New York: Missionary Education Movement of the United States and Canada, 1913), pp.240-241. 
Characteristics of the 1911 Revolution contributed much to missionaries' high evaluation of it. First, as F. L. Hawks Pott noted, the revolution was accomplished in a remarkably short period: four months. ${ }^{29}$ Arthur J. Brown acclaimed, "Never was so vast a Revolution so quickly and peaceably consummated.... The tide of victorious revolt had swept down the Yang-tze to the sea." 30 S. S. Hough, general secretary of the Foreign Missionary Society of the United Brethren Church, even used a biblical prophecy for Israel to describe the foundation of the Republic: "A new republic was organized, and China, with one-fourth of the world's population, thus suddenly passed through the most colossal transformation known in history. Truly, the hour had come for God to fulfill prophecy, 'a nation born in a day." "31 Second, the 1911 Revolution was a peaceful one. For Chinese, the 1911 Revolution, compared to the Taiping Rebellion, spilled little blood yet achieved great outcomes. "That such a tremendous change should have been carried out with so little real loss of life is remarkable," The Chinese Recorder editorialized. ${ }^{32}$ For foreigners, especially missionaries, "Throughout the Revolution the attitude of marked consideration toward Missions and missionaries made the uprising an entirely different one from the Boxer movement in its effects upon foreign missions." 33 Missionaries highly evaluated the revolution on account of its respect for human life and friendly attitude toward missionaries.

Religious factors played an important role in changing the views of missionaries. The Chinese Recorder, in December 1912, two months after the revolution ended, editorialized, "A stupendous Revolution is in progress looking to the establishment of many of the ideas Christianity had advocated. Unless the signs fail, the end of the present Revolution will mean a wider field and greater freedom of action for Christianity." ${ }^{4}$ The first fruit of the revolution was that religious liberty was granted in the Constitution to everyone. Chinese leaders, and even commoners, thought that Christianity helped foment the revolution. Sun Yat-sen, visiting a church in Beijing in 1912, said that the revolution could not have succeeded without the aid of the missionaries and the Christian church. Yuan Shikai once said to H. H. Lowry,

29 F. L. Hawks Pott, The Emergency in China, p. 37.

30 Arthur J. Brown, The Chinese Revolution, p. 145.

31 G. M. Mathews and S. S. Hough, The Call of China and the Islands: Report of the Foreign Deputation, 1911-1912 (Dayton, Ohio: Foreign Missionary Society, United Brethren in Christ, [1913?]), p. 12.

32 Editorial Board, "The Abdication," Chinese Recorder 43 (March 1912): 125.

33 Arthur R. Gray and Arthur M. Sherman, The Story of the Church in China (New York: Domestic and Foreign Missionary Society, 1913), pp.332-333.

34 "A New Era," Chinese Recorder 43 (December 1912): 675. 
"You have been teaching that there is one true God, before whom all men stand as equal brothers. And you cannot teach that kind of doctrine without leading to the sort of revolution that occurred in China." 35 This kind of interpretation strengthened missionaries' enthusiasm for China. It is well known that among the leaders of the revolutionary party were many Christians, such as Sun Yat-sen, Wang Chong Wei, and C. T. Wang. These Christian revolutionaries demonstrated the essential patriotism of the Chinese Christian and would not be called "church people" (as the government pejoratively referred to Chinese Christians). ${ }^{36}$

The 1911 revolution actually changed missionaries' view of China and the Chinese. When Sherwood Eddy, secretary of the Young Men's Christian Association for Asia, traversed Asia in 1912-1913, he saw that "a burning patriotism is sweeping through the younger generation of China and rapidly extending even among the masses. It was a strange sight to see student audiences in China with every cue gone and with them the whole conservatism of the past 4,000 years suddenly cast away."37 Arthur J. Brown repeated this point in The Chinese Revolution: "The individual Chinese is one of the most virile, industrious and self-reliant men in the world.... Chinese individuals are being welded in the fires of modern life into a Chinese nation." 38 Denying the view that China seemed to be an exception to the universal law of progress, never advancing, yet despite the grossest maladministration of government, never decaying, Arthur H. Smith wrote, "In the deliberate step of adopting the republican form of government for their expansive and disjointed country, the revolutionary leaders have accomplished the moral miracle of bringing China into world currents."39

Great changes followed the 1911 Revolution: the adoption of the Western solar calendar, the cutting off of the queue, a new style of clothes, etc. Arthur M. Shorrock saw in these changes outward indications of a thorough mental conversion: "The 1911 Revolution was more than a change in politics. It has meant a complete turn-about-face in everything.... China may be no longer characterized as looking backward but as looking forward."40 In discussing the revolution, Charles E. Scott, who had been a student of Woodrow

35 Paul Hutchinson, China's Real Revolution (New York: Missionary Education Movement of the United States and Canada, 1924), p. 155.

36 F. L. Hawks Pott, The Emergency in China, p. 65.

37 Sherwood Eddy, "Amazing Renaissance Is Now Sweeping All Asia," New York Times, November 23, 1913.

38 Arthur J. Brown, The Chinese Revolution (New York: Student Volunteer Movement, 1912), pp. 192-193.

39 Arthur H. Smith, The Uplift of China, rev. ed. (New York: Missionary Education Movement of the United States and Canada, 1912), p. 214.

40 Arthur R. Gray and Arthur M. Sherman, The Story of the Church in China, p. 334. 
Wilson's at Princeton University, enthusiastically stated, "[China] is rousing itself from the torpor of ages and under the influence of new and powerful revolutionary forces." 41

Missionaries were optimists. Although they saw difficulties besetting the country - such as the size of the country and population, the lack of general education and a communication system, and a loose political federation - they still had faith in China's future. F. L. Hawks Pott and J. W. Bashford used the precedent of America to encourage Chinese. Pott wrote, "When the United States gained her independence, there followed a period somewhat similar to that through which China is now passing. The conflicting interests of the colonies and their loose federation seemed to make it impossible for them to become a strong united nation. Many predicted the speedy disintegration of the new republic." 42 These writers believed that China could surmount all obstacles and establish a stable government. Sherwood Eddy also showed his faith in China in an essay in the New York Times: "The widespread demand for a republic and the recent change of government was a striking evidence of the new spirit of nationalism and patriotism that has pervaded the Chinese people, and so strong is the demand for it today that, despite local disturbances, democratic and republican government can probably never again be permanently overthrown in China." 43

The mission movement was a modern worldwide movement. Some missionaries focused on the significance of the Chinese 1911 Revolution to the world. Comparing the 1911 Revolution to the Crusades, Arthur J. Brown wrote, "As a new Europe followed the Chaos of the Crusades, so a new Asia will follow the chaos of the present Revolution." 44 Arthur H. Smith even declared, "Unless the history of the past is itself one great illusion the entrance of China upon a new national life is of deep and permanent significance, not to the Far East alone, nor yet to Asia, but to the whole inhabited world." 45 For missionaries, a Christian China might mean a Christian world.

Missionaries' descriptions and interpretations of the 1911 Revolution, whether correct or reasonable, were not so important as their influence on American conceptions of the revolution. Keith M. Kindred analyzed reports from China in four missionary periodicals published between 1905 and 1915,

41 Charles Ernest Scott, China from Within: Impressions and Experiences (New York: Fleming H. Revell Co.), p. 19.

42 F. L. Hawks Pott, The Emergency in China, p. 57.

43 Sherwood Eddy, "Amazing Renaissance Is Now Sweeping All Asia," New York Times, November 23, 1913.

44 Arthur J. Brown, The Chinese Revolution, p. 191.

45 Arthur H. Smith, "The Relation of the Chinese Revolution to Human Progress," Chinese Recorder 44 (January 1913): 13. 
including the Congregational Missionary Herald, The Baptist Missionary Magazine, the Methodist Episcopal Woman's Missionary Friend, and the interdenominational Missionary Review of the World. China was the most important field of the American mission, but did not occupy much space in the four periodicals, according to Kindred's research. In October 1909, there were 22 items about China, 18 about Africa, 18 about India, and 11 about Turkey. As events relating to the 1911 Revolution became more numerous, coverage of China greatly increased in all four periodicals. For example, the February 1912 issue of The Missionary Review of the World had 27 items concentrating on China out of a total of 66 items about China - a 300 percent increase over coverage in the October 1909 issue. Similarly, in The Missionary Herald, the proportion of articles emphasizing China jumped from 19 percent in October 1909 to 41 percent in April 1912.46 While coverage of politics was unusual in missionary periodicals, coverage of the politics of China was irregular in the missionary magazines until political developments relating to the 1911 Revolution became more conspicuous. ${ }^{47}$

As James Reed pointed out, while the missionary message about the 1911 Revolution "was overly simple, so that the man in the pew heard less about anti-imperialism and nitroglycerine than about more comforting themes, it did not lack sympathy for China." Similarly, The Christian Observer briefly wrote, "The ideas that have awakened this great people, slumbering for millenniums, have been introduced into China by missionaries." 48 Features of this "patter" of items were, one, most of these items were relatively brief, and two, most of the articles of this type did not attempt to report on and/or analyze the political situation in China. ${ }^{49}$

In treating the 1911 Revolution, the four periodicals was uniform on one keynote: not a single article in the four periodicals that Kindred examined could be construed as supporting the Manchu rulers. The articles sought to convince readers that although the Chinese had little experience with republican government, they had the capacity to rule themselves. Many articles argued that the Chinese could conduct this type of government, though they usually expressed some concern over their lack of experience with democratic

46 Keith Matthew Kindred, "Images of the Chinese as Presented in American Protestant Missionary Periodicals, 1905-1915," pp.41-42.

47 Keith Matthew Kindred, "Images of the Chinese as Presented in American Protestant Missionary Periodicals, 1905-1915," p. 66.

48 James Reed, The Missionary Mind and American East Asia Policy, 1911-1915, p. 126.

49 Keith Matthew Kindred, "Images of the Chinese as Presented in American Protestant Missionary Periodicals, 1905-1915," p. 60. 
concepts. ${ }^{50}$

American churchgoers clearly felt and responded to missionaries' optimism about China's future and Christianity's place therein. While contributions for all church expenses rose nearly 40 percent between 1904 and 1914, contributions for foreign mission work grew by more than 85 percent during the same period. ${ }^{51}$ Moreover, between 1911 and 1915, mission-board secretaries gave more attention to China than to any other country, sinking around one-third of their resources in China. Over 1,000 new missionaries went out to China during the period from 1911 to 1916.52

In response to missionary information coming out of China, missionaries and American Christians took actions to urge the U.S. government to recognize the new republic. Christianity had an important impact on the foreign policy of the Woodrow Wilson administration. In his excellent study The Missionary Mind and American East Asian Policy, 1911-1915, James Reed found that missionaries had a decisive influence on Wilson's early diplomatic policy, especially on the recognition of the Republic of China. In Madison, New Jersey, nineteen citizens wrote to President Wilson and called upon him to help China "for the sake of Christianity and for the uplift of Chinese people," and in Oregon, a thirteen-year-old girl received a prize for her essay "Why the United States Should Be the First Nation to Recognize the New Republic of China."53 The business community was cautious; ChineseAmericans and Chinese students had little influence on American opinion; newspaper editors reported much less on China after the Manchu dynasty abdicated in February 1912; Roman Catholics and other ethnic Americans remained unaffected; and pro-Chinese opinion continued to build during 1913. From all these factors, we can see that only the Protestant missionary enterprise possessed both the sustained will and the communications system required to effect such a massive movement of public opinion. ${ }^{54}$

In the early twentieth century, Europe was still the center of the world in American eyes. At that time, churches, the dominant social and cultural institution, played an important role in Americans' lives. As Michael V. Metallo said, "When academic study of China was minimal, missionaries were

50 Keith Matthew Kindred, "Images of the Chinese as Presented in American Protestant Missionary Periodicals, 1905-1915," p.65.

51 Michael V. Metallo, "Presbyterian Missionaries and the 1911 Chinese Revolution," Journal of Presbyterian History 62, no. 2 (summer 1984): 157.

52 James Reed, The Missionary Mind and American East Asia Policy, 1911-1915, pp. $17-18$.

53 James Reed, The Missionary Mind and American East Asia Policy, 1911-1915, pp. 26, 132.

54 James Reed, The Missionary Mind and American East Asia Policy, 1911-1915, p. 145. 
uniquely placed to help shape American ideas and attitudes about that country, providing information through a variety of means." 55

In addition to political upheaval, missionaries also noticed societal reforms. One article in the May 1913 issue of The Missionary Review of the World commented on reform efforts in all areas of Chinese society, not just politics. The Chinese were capable of carrying out such reforms only under the influence of Christianity. ${ }^{56}$ Sherwood Eddy noted the reform of education (especially female education); the abolition of footbinding, opium, gambling; and the rise of a new consciousness in China. Most of these reforms had been part of the late-Qing reforms even earlier, so in discussing China in American eyes, we have to pay attention to the sequence of historical events. Michael V. Metallo wrote, "In no other period in the twentieth century was this optimistic assessment so pervasive among missionaries than from about 1900 to the 1911 Revolution and its immediate aftermath, when all the hopes of success for the missionary endeavor seemed to be realized with startling swiftness." 57

The reforms in the late-Qing period, the 1911 Revolution, the foundation of a republic, China's apparent receptivity to change, and its movement toward modernization brought a great upsurge in a positive missionary attitude toward China. Missionaries' optimism greatly affected Americans, who believed they had contributed to the reform of China. The result was that "Americans found grounds for self-congratulation. They could feel humanitarian, altruistic, and righteous. In this frame of mind there was less room for the usual image to command a large place in the American imagination than there had been earlier in the period." 58

Harold Isaacs, who widely surveyed American opinion of China, termed the years 1905 to 1937 "the age of benevolence." 59 In the early twentieth century, missionaries sought to reshape China in the American image, both along Christian and democratic lines. Although their descriptions of changes in China did not completely alter the image of China at that time, they did plant "friendly seed." Many books by missionaries were collections of speeches at institutions of higher learning. For example, Arthur J. Brown's

55 Michael V. Metallo, "Presbyterian Missionaries and the 1911 Chinese Revolution," p. 157.

56 Keith Matthew Kindred, "Images of the Chinese as Presented in American Protestant Missionary Periodicals, 1905-1915," p. 45.

57 Michael V. Metallo, "Presbyterian Missionaries and the 1911 Chinese Revolution," p. 153.

58 John Berdan Gardner, The Image of the Chinese in the United States, 1885-1915, p. 170.

59 Harold R. Isaacs, Scratches on Our Minds: American Images of China and India (New York: John Day Co., 1958), p. 71. 
New Forces in Old China and Charles E. Scott's China from Within were speeches at Princeton Seminary, and William N. Brewster's Evolution of New China was a series of addresses at the Theological School of Boston University. Several books by Arthur H. Smith were used as textbooks for Asian study in colleges. These books had an impact not only on Americans at that time, but also on the next generation. Harold Isaacs's survey indicated that a "more tolerant and sympathetic view was beginning to appear more commonly in the 1930's." 60 Along another dimension, missionaries' sentiments and experiences had profound influence on their children, the most remarkable being Pearl Buck, the Pulitzer- and Nobel-prize winning author, and Henry R. Luce, the founder and editor of Time, Life, and Fortune. They played a significant role in shaping popular perceptions during the 1930s and 1940s. ${ }^{61}$

The Research for this article was supported by Program for New Teacher Research in China University of Political Science and Law (2013), and by Program for Young Innovative Research Team in China University of Political Science and Law (2014CXTD10).

60 Harold R. Isaacs, Scratches on Our Minds: American Images of China and India, p. 132.

61 Jespersen, Thomas Christopher, "The American Century in China: Henry Luce, United China Relief, and the Creation of American Perceptions of China, 1931-1949," doctoral dissertation, State University of New Jersey, 1991, p. 9. 
